\title{
Maltese Ceramics and Imperial Foodways: an exploration of nineteenth-century red wares
}

\begin{abstract}
The archaeological study of recent periods in Malta is in its infancy. Despite the high potential for an historical archaeology of Malta contributing to broader issues such as an understanding of Mediterranean trade and colonialism, as well as the cultural history of Malta, the archaeological resource has remained under-explored. The aim of this article is to address the situation and offer an initial classification and interpretation of local and imported red earthenware ceramics. It will demonstrate the need for such work in relation to answering questions relating to local production, international trade, and foodways.
\end{abstract}

\section{Keywords}

Ceramics, Malta, historical archaeology, British Empire, colonialism, foodways.

\section{Introduction}

Historical archaeology ${ }^{1}$ is only just starting to take hold in Malta. Despite traditions of Braudel-inspired studies of the longue durée in the Mediterranean (for example see Barker 1995; Vroom 2003; Bintliff 2012; Vionis 2012) and the development of post-medieval archaeology in neighbouring Italy (Milanese 2007), archaeological studies in and of Malta have predominately focused on periods of pre- and proto-history. Medieval and later periods have been extensively studied by historians and art historians, but few archaeologists have been so inclined, resulting in a relative paucity of relevant published works when compared to earlier periods. However, a start has been made. An environmental study of post-medieval field systems has uncovered probable patterns of 'cereal cultivation and stubble burning,' as 
well as evidence for cotton cultivation in the rural Mistra Valley (Hunt and Vella 2008, 6364), and more recent human-made landscapes have been included in geomorphological studies (Devoto et al. 2012). A study of irrigation systems has recorded post-medieval features such as rock-cut channels and nineteenth-century water lifting machinery (Saliba, Conti \& Borg 2002, 44), and the relationship between corbelled stone huts (giren), farming, and livestock rearing has been explored by Michael Fsadni (1999). Maritime interventions include the Malta Cistern Mapping Project, which includes studies of cisterns constructed up into the sixteenth century (White et al. 2010), harbour surveys (Atauz 2000; Atauz \& McManamon 2001), and explorations of traditional boat forms (Muscat 2005). Finds-based studies date from the 1977 excavation of the chapel at Hal Millieri, the publication of which provides one of the first accounts of medieval finds in Malta (Blagg, Bonnano, \& Lutteral 1990). Several more recent papers address medieval ceramics (Bruno \& Cutajar 2013; Buhagiar 2012; Mollinari \& Cutajar 1999) and early modern finds were included in a multiperiod ceramic characterization project (Mommsen et al. 2006). Tobacco pipes from several assemblages have been studied and published by John Wood (2008; 1998), and the on-going Malta Survey Project continues to collect and analyse artefacts from prehistory to the present (Docter et al. 2012).

Despite the positive increase in post-medieval studies in Malta, core facets of archaeological study such as a basic ceramic typology and chronology remain wanting. The scarcity of previous research and the unavailability of appropriate assemblages has often resulted in enthusiastic yet imprecise labelling of later ceramics with catch-all terms such as 'china,' being applied to all white-bodied British ceramics, and 'red wares,' which has been used as a shorthand for a range of coarser fabrics (see Hahs 2010).

In this paper I will take up the challenge of offering an initial classification of local and imported red earthenware ceramics based on nineteenth-century assemblages recovered 
from the site of the Inquisitor's Palace Museum. The aim is to provide an initial typology of forms and fabrics which may form a basis for my own and others' further research, and to use the material to explore local production, international trade, and foodways. After sketching the historical background to post-medieval Malta and the Inquisitor's Palace, I shall present the forms and fabrics of the red wares, and will then consider the red wares in light of local production and eating traditions.

\section{Historical Background}

In 1530 the Order of the Knights of St John of Jerusalem took up residence and ruled Malta until ousted by Napoleon in 1798. French rule was unpopular and resulted in a MalteseBritish alliance that forced the French garrison to leave the islands after only eighteen months. In 1800 an unofficial British occupation of the islands began. They were officially annexed into the British Empire in 1814, with the Treaty of Paris, and remained so until independence in 1964 (Blouet 1972). During the nineteenth century, Malta was home to thousands of British troops and officers at any one time; sometimes for months, sometimes years (Malta Blue Books $[M B B] 1855)$. Its strategic significance as a permanent military base and control point for imperial trade interests in the Mediterranean and, via Suez, India meant that Malta became enmeshed within networks of global trade and communication (Refalo 2010, 7-8). Goods from around the world flowed through her warehouses, but little is understood about the ways in which the availability of new products affected foodways and local cooking traditions. A thriving 'British' population quickly developed around the harbours (Cassar 1988, 94-97), initially made up of military and associated personnel but later a whole range of administrators and merchants who replicated many of the services, social activities, and norms of Victorian England. Accommodation had to be found for the expanding military 
population and although many barracks and mess houses were newly built, existing buildings were also converted (Bonnici \& Cassar 2009, 144).

\section{The site}

The Inquisitor's Palace Museum (3553'13.54"N; 14³1'21.62"E) ${ }^{2}$ is situated across the Grand Harbour from Valletta, in Birgu (Vittoriosa), and is today owned and managed by Heritage Malta (Fig. 1). The building was largely constructed in the mid-sixteenth century as a civil court by the Knights who, after the Great Siege of 1565 , moved their main residence to Birgu before building Valletta (Mallia-Milanes 1993, 3). Shortly after being abandoned by the Knights, the building was taken over by the Holy Office as the official residence of the Inquisitor in Malta (Vella 2013, 13). When ousted by French forces in 1798, the site became the residence of the French commander of the area (Gambin 2003, 24). With the arrival of the British, the building was put to use as a military infirmary and, subsequently, an officers' mess (Badger 1869, 247; Tallack 1861, 83-84); however its exact function at any given time during the nineteenth century is far from being understood. In the 1920s, the building became a museum (Gambin 2003, 27) and after WWII was used to house homeless Dominicans (Gambin 2003, 32). The additions and reworkings by almost every occupant have resulted in a complex structure which is only just starting to be understood (Vella 2013).

Between 1998 and 2002 several archaeological interventions were conducted under the joint guidance of Kenneth Gambin (Heritage Malta) and Nathanial Catajar (Superintendence of Cultural Heritage). The excavations coincided with redevelopment and restoration works being carried out in the museum and were exploratory in nature, focused on determining the building sequence of specific areas within the complex. The excavations on which this paper is based are those of a cistern referred to as the 'Garden Well' (IPM-GW), a cess pits in the old prison block (IPM-CPMC), and the levelling down of an area which is 
referred to as the prison yard (IPM-MPY) (Fig. 2). Additional material was recovered when an electric company made a discovery, which is referred to as the Enemalta Store (IPM-ENE). Sadly, reports of the excavations were never completed and the resultant assemblages have until now not been systematically studied. As such, this study represents the first detailed archaeological study of post-1500 ceramics and glass in Malta.

The assemblages appear to be the result of dumping activities which were part of nineteenth-century re-modelling. Waste material was used to raise and level floor surfaces, as I was able to see first-hand during building renovations in October 2013. The assortment of large fragments, co-joining sherds, and unworn breaks suggest that the contents of the assemblages are chronologically homogenous.

\section{Methodology}

Due to the lack of any previous published work or reference collection on which to base analysis, an analytical approach has been taken when recording and classifying the coarse ware ceramic sherds. At the descriptive level, fabric, surface treatment, decoration, vessel part, vessel form (where known), mode of production, firing conditions, and context were recorded. For the ceramic fabric colour was recorded using a Munsell Soil Chart; inclusions according to Peacock's (1977, 30-32) identification guide, and hardness based on a simplified Mohs scale (very hard: cannot be scratched with a steel blade; hard: cannot be scratched with a finger nail; and soft: able to scratch with a finger nail). Observations were recorded with the aid of hand lenses and digital photographs, which were enlarged on-screen. Classification of inclusion density, dispersion, and size are all based on those set out in Orton and Hughes's Pottery in Archaeology (2013, 282-83). Minimum numbers of vessel counts (MNV) are based on the total count of rim sherds minus any co-joining rim sherds. Base sherds are not included in the calculation of MNV. 


\section{Overview and dating of the assemblages}

The assemblages consist predominantly of ceramics and glass both by sherd count and weight, but also include some finds of metal, leather, mortar, plaster, shells, stone, and wood (see Tab. 1; Fig. 3). The glass finds include bottles, drinking vessels, and decorative nondrinking tableware. A significant bone assemblage was recovered for IPM-MPY, which has not yet been studied. The assemblages also contain large blocks of decorative architectural masonry, which have not been recorded as part of this project.

The ceramic signature of the site consists mostly of red wares, with imported stone wares, buff earthen wares, whitewares and porcelains accounting for less than $10 \%$ each by sherd count or MNV. Red wares are here defined as iron-rich oxidized fabrics that are not coated with a tin glaze. The stone wares are predominantly British (stamped 'London'), together with some Dutch gin bottles inscribed with 'Schiedam.' The 'white' earthenware (including creamware, pearlware, and transfer-printed whiteware) and porcelains account for $12.9 \%$ of the sherds and $18.6 \%$ by MNV, reflecting the practice of regiments taking their possessions with them when the move on. A range of buff-coloured wares account for $9.3 \%$ of the sherds, and $7.1 \%$ by MNV. A small amount of tin-glazed sherds were recovered $(3.1 \%$ by sherd count, $4.0 \%$ by MNV).

Due to the presence of nineteenth-century British ceramics, it is most likely that the deposits are associated with the building's occupation by British officers. While historical accounts indicate that the site was used as an officers' mess by the 1860s (Tallack 1861, 8384), the assemblages suggest an earlier date. Several termini post-quem are provided: the base of a blue and white transfer-printed vase (IPM-MPY.3.113), base marked 'R. W \& B.' represents Robinson, Wood and Brownfield, who, according to Coysh and Henrywood (1982, 
304) were producing under that name for a short time in the 1830s; and two examples from Spode (IMP-MPY.1.2-3 and IMP-MPY.3.51, fig. 4a) suggest production dates before 1850. Furthermore, the last two items have regimental associations painted on the bases, 53rd and 44th Foot respectively, which can be traced to Malta sometime before 1851(Cannon 1847, 26-27; Carter 1864, 166-167). The presence of creamware, a small amount of pearlware, many early to mid-nineteenth-century bottles, and the absence of identifiably late nineteenthcentury material suggests that the dumping and re-modelling took place sometime in the 1860s or possibly 1870s. This would date the use of the material in assemblages IMP-CPMC, IMP-GW, and IMP-MPY to a date range of c. 1850-1860. The presence of London stoneware bottles exhibiting the names of Maltese traders and contracting companies such as 'Mortimer \& Co,' known to have been active between 1882 and 1905 (Egyptian Gazette 1882, 1; London Gazette 1905, 3930, fig. 4b), suggests that the IMP-ENE has as later, early twentieth-century deposition date. The difference in date of the three excavated assemblages and the discovery of material in a walled-up crevice (IPM-ENE) most likely relates to the nature of their deposition. IPM-CPMC, IPM-MPY, and IPM-GW are considered largely contemporaneous acts of deposition, when existing 'rubbish' was used as construction fill in renovations that took place in the second half of the nineteenth century. Together the assemblages can be seen to represent a date range of c.1850-1910. Detailed information regarding the archaeological stratigraphy was not recorded during excavation.

\section{Fabrics and typology}

The percentages given below are based on the total percentage of red wares by MNV (Tab. 2). The most abundant wares are local (MNV 83, 55.7\%), followed by a range of Mediterranean imports (MNV38, 25.5\%), and a significant amount of Sicilian ware (MNV 28, 18.8\%). Individually, IMP-CPMC appears to contain more imported than local material, with half the 
MNV recorded being unidentified probable imports (Fig. 5 \& Tab. 3). The other three assemblages are dominated by locally produced wares. The significant proportion of Sicilian Patti ware in each assemblage suggests that this imported ware played an important role in the everyday activities of those cooking at the Inquisitor's Palace in the mid-late nineteenth century.

\section{Mediterranean imports}

\section{Sicilian red ware}

The Sicilian Patti ware has been identified through visual comparison with published examples (Milanese 2010, 89-90) and communication with Marco Milanese (University of Sassari). The hard, fully oxidized fabric is red (2.5YR 4/6), reflecting an iron-rich clay source (MNV 28, 18.8\%). It contains sub-angular grains of less than $2 \mathrm{~mm}$ and irregular-shaped voids which together account for $10 \%$ of the matrix. Twenty-eight MNV were counted and three main forms identified, each with sub-types. All vessels have a smooth surface, with a colourless lead gaze coating the interior and often the upper portion of the exterior. Historical accounts attest to 'jars and utensils' being exported from Patti in 'very large quantities to Malta' (Blaquiere 1813, 397). Sooting on examples from all forms except the bowls demonstrates their use as cooking vessels.

Five types of cooking pot ( $9 \mathrm{MNV}, 6.0 \%$; Fig. 6a) are distinguishable; the first three of which are globular or rounded in profile and handleless. They have everted rims with types 1 (Fig. 7d) and 3 exhibiting a slight internal flange (rim diam. 120-130 mm). Type 3 differs by the presence of an extended neck. The other two forms (types $4 \& 5$ ) have two opposing round loop handles and simple rounded rims (rim diam. 140-180 mm). The profile of type 5 is markedly more cylindrical in profile than the globular form. The first type is the only 
decorated form, with a continuous incised line and rouletting above and below the shoulder, respectively.

The flat-based cooking pans (MNV 13, 8.7\%; Fig. 6b) can be broken down into three types, which are all wide and shallow, decreasing in size (rim diam: Type 1, 160-240 mm; Type 2, 200-210 mm; Type 3, 120-150 mm), and are separated by the positioning, number, and type of handle. Together they make up $46.5 \%$ of the Sicilian wares. Type 1 -tigan (Lanfranco 1986, 16; figs. 7a, b, c) —is wide and shallow with an interned profile from base to rim and has two opposed round handles. The flattened rim is clubbed on the interior. Types 2 and 3 have straight profiles and simple upstanding rims. The unknown handle of type 2 extends above the rim, possibly as a loop or simple lug. Type 3-pagna (Lanfranco 1986, 16) - is a skillet with a single hollow rod handle protruding from the upper part of the vessel.

The last group of identifiable vessels from this iron-rich fabric is a group of bowls (MVN 4, 2.7\%; rim diam. 200-320 mm) that can be sub-divided into those with deep halfrounded bodies (Fig. 6c) and those with a shallower, more conical profile (Fig. 6d).

\section{Other imports}

A number of notable forms exist within this broad group, including bowls, storage vessels, a globular pot, jugs, and several tiles. Any fabric that cannot be positively grouped into either the local or Sicilian wares has been categorised as 'other imports.' A limitation of this conservative method of archaeological classification is that some fabrics and forms dealt with as imports may in fact, after chemical or mineralogical study, turn out to be local products.

The dishes (MNV 11, 7.4\%) include a group of small dishes in a range of oxidized red wares, and a footringed bowl with a flared body and an inturned rim (rim diam. 110 mm; Fig. 8a). A larger dish with a rounded profile, unknown base and everted rim (rim diam. $360 \mathrm{~mm}$; Fig. 8b) was also identified. Sherds from several storage vessels were found including a 
water storage and transportation jar (MNV 1, 0.7; Fig. 8c) similar to that identified in local fabrics and a jar with a thick everted rim and unknown body/base (rim diam. 260 mm; Fig. 8d). A single lead-glazed globular pot (MNV 1, 0.7\%; Fig. 8e) was found that has a cylindrical neck, clubbed rim (rim diam. $150 \mathrm{~mm}$ ), and a possible looped handle that extends above the rim. No soot was found to suggest that this vessel had been used for cooking. Two forms of jug were found (both MNV 2, $1.3 \%$; figs. 8 f \& 9), the most complete being flatbased with a wider base than mouth (Fig. 4f). A single looped strap handle extends from the rim to the central body. In profile it is rounded, with a constricted neck opening to a wider mouth. The exterior surface appears to be treated with a degraded cream slip, with no interior surface treatment. Fragments of hard, high-fired drainage pipes and possibly roof tiles have also been recovered.

The provenance of these imports has not yet been determined and it may be that, in some cases, similarities with the forms identified as local may be a result of the conservative method used to determine which fabric types were local. The intensive contact with Barbary and Tunis adds another unknown dimension to provenancing, due to the lack of ceramic studies in nineteenth-century North African contexts. It is probable, though, that most originate from the Mediterranean region.

\section{Local wares}

The local red wares have been identified by selecting the most common forms across a range of similar fabrics (MNV 83, 36.6\%). The forms are a brazier with unique Maltese form (see explanation below), a simple bowl, and a typical Maltese water carrying/storage jar, known from illustrations (see fig. 10). The selection process is conservative and most likely excludes a few fabric types that may in fact be local but do not meet the selection criteria. The local wares are all hard, light red (10YR 6/6) or reddish yellow (5YR 6/6, 7.5YR 6/6 or 2.5 YR 
5/6), and contain similar sized sub-angular to sub-rounded light and dark coloured quartz grains $(0.5-1.0 \mathrm{~mm}$, exceptionally up to $3.0 \mathrm{~mm}, 5-10 \%)$, which correlates with the acidinsoluble residues found in the Blue Clay Formation (Digeronimo, Grasso \& Pedley 1981, 178). The presence of carbonate particles and clay pellets demonstrates a possible similarity, to fabrics MALTA-C-A and MALTA-C-2 (Schmidt \& Bechtold n.d., 3), thought to be made near Tas Silg and recovered from the Roman Villa at Żejtun. All fabric types contain irregular-shaped voids $(0.5-2.0 \mathrm{~mm}, 5 \%)$ and show the presence of iron ore, sometimes totally burnt out, at other times not (Fig. 11). The occasional presence of a blackened, reduced core is taken to reflect firing practices and not fabric constituents. None of the local fabrics are glazed.

The bowls (MNV 41, 27.5\%) are the most numerous red ware form and fall into two main types. Bowl type 1 (MNV 22, 14.8\%; Fig. 12a) is a simple flat-based, rounded with a simple rim that can be upright or slightly turned in. Shallow to medium in depth, in profile the bowl is either rounded or slightly carinated. This common form shows great variety in size (rim diam. 140-480 mm) and is usually given a polished interior and sometimes exterior finish. Similar shaped burnished bowls also made of a local sand-tempered fabric were found in medieval contexts at Hal Milieri (Blagg, Bonanno, \& Luttrell 1990, 72-73). Bowl type 2, or żingliet — 'a large earthenware basin'-(Aquilina 2006, 412), is a deep, flared, flat-based bowl with a squared or hammered rim (MNV19, 12.7\%; Fig. 12b). The multi-sized form remained popular in Malta, and later versions often have colourless or green-tinted glazed interiors, although the nineteenth-century examples appear all to be unglazed.

Although braziers have a long history in the Mediterranean region (see Leonard 1973; Vroom 2005, 20-21), none appear to have the same form as the Maltese kenur tal-fuhhar (MNV10, 6.7\%; figs. $13 \& 14$ ), which is a thick-walled, heavy vessel and is distinguished by its relatively broad body circumference ratio height, often giving it a rather squat appearance. 
Largely cylindrical in profile, the base is often slightly pedestalled with a body that tapers slightly inward to an elongated outward-jutting rim with a simple or thorned lip (rim diam. $160-350 \mathrm{~mm})$. The interior is divided by a shelf ring which is situated approximately twothirds way up the body, separating fuel from food and providing a reception platform for vessels. The kenur tal-fuhhar is the only decorated local vessel, with some sherds displaying painted geometric patterns and stripes in white slip.

Another typical Maltese form is a water-carrying jar (MNV 4, 2.7\%; Fig. 12c), similar to those depicted in illustrations of nineteenth-century Maltese life (Fig. 10). They have a flat base which gives way to an obtuse-angled, amphoroidal body. On top of the shoulders sits a restricted neck with an upright rim (rim diam. 70-135 mm). Two opposed small loop handles or lugs are applied to the shoulder and neck.

Storage vessels (MNV 5, 3.4\%) fall into two main types. Type 1 is a tall, narrow, shouldered jar with a slightly flaring lower body and an inward sloping shoulder (Fig. 12d). The shoulders give way to an everted collar with a slightly inturned rim (rim diam. $160 \mathrm{~mm}$ ), and a narrower mouth than base. The second type represents a group of jars with a flat base giving way to an obtuse-angled body (Fig. 12e). They have simple, rounded rims (rim diam. $220-400 \mathrm{~mm}$ ) and an applied finger-pinched strip or thorn approximately $25 \mathrm{~mm}$ below the rim.

The Enemalta store contained three complete oil lamps, or musbieh, which are all small (rim diam. 60-70 mm, height 30-48 mm), hemispherical, with sooted trefoil pinched wick lips (MNV 3, 2.0\%).

\section{Local ceramic production}

Little is known about nineteenth- and early twentieth-century ceramic production in Malta. The main sources of information are historical eye-witness accounts and a two-page study 
published in 1921 (Buxton \& Hort). Production was small-scale and based around family groups in villages, and although it probably occurred at many sites, only Birkirkara $\left(35^{\circ} 53^{\prime} 48.00^{\prime \prime N} ; 14^{\circ} 27^{\prime} 45.00^{\prime \prime E}\right)$ and Żejtun $\left(35^{\circ} 51^{\prime} 22.02^{\prime \prime N} ; 14^{\circ} 31^{\prime} 59.72 " \mathrm{E}\right)$ are recorded (Pullicino 1947, 332). Buxton and Hort describe two methods: an older using a hand-spun wheel and a newer that employed a kick-wheel which was introduced in the early twentiethcentury. They observe that in the older hand-wheel method the clay is 'rolled in sand, and then a flat piece is laid on the disc, which is set spinning by hand in a clockwise direction' $(1921,130)$. The process of polishing the surfaces of leather-dry pots with a pebble is also recorded, and was found on the simple bowls. They also note the absence of glazed and slipped wares. The 'simple' kilns are bricked up when firing and predominately fuelled by brushwood or occasionally wood from broken-up boats. The potters reported that the 'clay has to be fired slowly as it easily vitrifies, and the potters say coal is unsuitable as it gives too hot a fire' (Buxton \& Hort 1921, 131). The use of uncontrollable fuel sources such as brushwood may account for the core reduction found on some sherds, as well as the lack of glazing. The clay used by the Birkirkara potters was found on the surface nearby, and was mixed with sea sand. The outcropping clay is likely to have been part of the Fiddien soil series which contains calcareous olive (5Y 5/3) clays with iron stains (Lang 1960, 35). Under oxidising kiln conditions the iron would account for the red colour and the use of sea sand for temper correlates with the quartzite grains found in the recorded local fabrics. The clay used at Żejtun was apparently finer and imported from Gozo, 'where there is also a pottery industry' (Buxton \& Hort 1921, 130).

The nomenclature thus far employed has been based largely on publications by Maltese folklorist Guido Lanfranco and those suggested by the curators working with the ethnographic collections at the Inquisitor's Palace Museum. In their description of the vessels produced at Birkirkara, Buxton and Hort offer a different set of terms used by the potters 
(summarized in Tab. 4), some of which it is possible to correlate with forms found in the local fabrics. The 'olla, zir, and bombola may represent a finer sorting of the water-carrying jars which is not archaeologically visible, while khenur clearly describes the kenur tal-fuhhar (Figs. $13 \& 14$ ), as does musbih the simple oil lamps (misebieh). Their three types of flatbased bowl (lembi, mattrat, and lembieh) appear to describe the series of flared bowls (Bowl Type 2), which I have termed collectively as zingliet (Fig. 12b). From the range of sizes-the largest being 3 feet $(914 \mathrm{~mm})$ in rim diameter - it is unlikely these names could refer to the more simple Type 1 bowls. While these terms are useful and shed some light on the perceptions of, and differentiations, made by the potters, and their vessels' intended uses, it is important to bear in mind that present-day Maltese is far from being a standardized language, with much regional variety. It is likely, therefore, that the terms used by nineteenth-century potters may have varied from village to village, across time, and possibly across different users groups.

\section{New foodways and traditional cooking}

From the little evidence currently available, local and imported red wares appear to be spread across the island and are found in urban and rural contexts. In surface surveys carried out in 2005, David Hahs collected red wares from a range of rural sites. Although his photographs group all ceramic fabrics together, sherds of what appear to be the distinctive lead-glazed Sicilian ware from Patti exist in his assemblages from Ghemieri, Hal Muxi, Hal Tartarni, and Hal Xlug (Hahs 2010, 102-114), suggesting, should they turn out to be in fact Patti ware, that the ware was in common usage throughout the island. Patti ware also seems to have been found at the Auberge de Castille (Valletta) ${ }^{3}$ in an assemblage that appears to reflect the range of coarse wares and British imports recorded at the Inquisitor's Palace site (Buhagiar 1998), 
adding further credence to the notion that the red wares described above were used concurrently with British and other imports.

Furthermore, I have identified nineteenth-century British ceramics in assemblages collected by the Malta Survey Project, carried out in north-west Malta (see Docter et al. 2012), which, along with those collected by Hahs, suggest that British ceramics were widespread and being used by rural populations at least by the mid-nineteenth century. The marked difference in aesthetic qualities of wares has been previously used to suggest a difference between the material culture used by the colonial British and the Maltese (Buhagiar 1998), but rather the difference relates to the use of coarser local and Mediterranean wares for storage, transportation, and food preparation, on the one hand, and an increasing use of British table wares for eating and drinking, on the other.

One of the greatest culinary challenges in nineteenth-century and earlier Malta was fuel. The kenur, a square stone-carved stove, is reportedly the traditional cooking stove of Malta (Fig. 15). Like the smaller, more portable kenur tal-fuhhar, it could be fuelled with brushwood or anything else found to burn. Romantic poet Samuel Taylor Coleridge notes that it is the custom of the Maltese to 'dress their food out at their doors on pots of Fire' (1962, 2104 10.7), the 'pots of fire' presumably referring to the kenur or kenur tal-fuhhar. In 1812, John Galt refers to typical kitchens in which 'stoves were so arranged, as to occasion no inconvenient heat, and to require very little fuel' $(1812,123)$. By the nineteenth century, it would appear that charcoal was the main source of fuel—for those who could afford it—with large quantities being imported in the 1830s (MBB 1829-1839). ${ }^{4}$ In the late nineteenth and early twentieth centuries Malta was known as the coaling station of the British Mediterranean, but the open-fire form of cooking used would have prevented the immediate conversion to coal, due to the fuel's toxic qualities. The relatively low heat emitted from such stoves suggests a reason for the tradition of slow cooking in Malta, which was based on grains, 
pulses, and vegetables - imported and home-grown - rather than meat, and the kenur talfuhhar would have served as a fuel-efficient and convenient way to reheat stews and broths. The relative small size and portability of the stove, even after the introduction of more modern kitchen appliances, may explain its continued use into the twentieth century. Its use to reheat and keep warm food, and possibly drink, is remembered by some from their midtwentieth-century childhood days, by which time a candle often replaced messier fuels (Cachia 2013).

Fuller kitchen ranges are a very recent phenomenon in Malta, but some buildings did have table-top cooking hobs. In a mid-nineteenth-century account, William Tallack describes Maltese kitchens that:

have no need for spacious fireplaces and ovens, as nearly all cooking operations are effected by means of a little charcoal on a flat round grating. The whole of an ordinary Maltese kitchen-fire resembles in size and shape a common dinner plate, covered with fragments of charcoal. A man-servant busies himself before one or two of these insignificant looking dull fires placed on the top of a stone bench. He frequently revives the embers by waving a sort of flapping brush, instead of using bellows (1861, 104).

Allusions to a lack of need for ovens suggests that 60 years of British occupation had not drastically changed Maltese cooking, although the use of bakeries' ovens on feast days is well attested to, with prepared meat, fish, or vegetable dishes being taken to the baker's to roast or bake (Galizia \& Galizia 1997, 82).

The mess house at the Inquisitor's Palace site was fitted with at least one kitchen, although an undated and anonymous nineteenth-century plan suggests the possibility of a 
second. ${ }^{5}$ The surviving kitchen (Fig. 16) was equipped with a sink, a cooking range and an oven. The exact dates of these features and their modifications are unknown, although all but the re-modelled oven probably pre-date the British period of occupation. Such a cooking range correlates well functionally with the Sicilian vessels identified. The flat-based tigan and pagna would have provided stability when cooking and the large open orifices would encourage excess liquids to evaporate, suggesting an increasingly drier, meat-rich, Britishinfluenced diet. The rations prescribed for the officers of the Royal Maltese Fencible Regiment in 1835 demonstrate a diet based on salted meats, biscuit, ${ }_{2}$ and bread, supplemented with fresh meat $(M B B)$. Over the course of the following 50 years the increased availability of fresh meat was due largely to the importation of bullocks. The Malta Blue Book of 1880 records the importation of over 10,000 live bullocks for consumption, with 5,127 coming from Barbary, 4,102 from Tunis, 468 from Algiers, and 310 from Russia. Once on the island, they were 'fed on cotton seed' which, according to Coleridge, resulted in a 'fat [that] congeals quickly \& sticks worse than suet to the roof of the mouth' (1962, 229421.478$)$. Despite the increase availability of meat, vegetables were still an important constituent of the diet. The globular cooking pots were needed to boil locally-produced and imported vegetables such as beans, peas, carrots, potatoes, cabbages, and cauliflowers (Martin 1837, 112). The potential increase in the use of metal cooking wares has left little archaeological trace, although a couple of sheet-pressed saucepans were found in the IPM-ENE assemblage.

The larger ceramic storage jars are likely to have provided rat-proof stores for dry foods including dried meats and pulses. It is unlikely that individual households would have kept large quantities of wheat or barley for the purposes of making bread, due to their inadequate baking facilities. Bread was bought from bakeries. Oil, predominately imported from Sicily and other parts of Italy, but also Greece, Turkey, and Egypt (MBB 1870-1880), would presumably have been stored in ceramic vessels, although it was most likely imported 
in barrels. The quantity of glass food, mineral water, and wine bottles, as well as stoneware ginger beer bottles, found in the Inquisitor's Palace assemblages suggests that mass-produced bottles had superseded earthenware vessels as the primary container for many liquids. The exceptions perhaps being water (evidenced by the water transportation vessels) and possibly inferior quality wine (imported in barrels). Both of the local bowl types appear to have been used in Malta for many centuries: medieval (twelfth century onwards) examples were found at Hal Milieri (Blagg, Bonanno, \& Luttrell 1990, 72-73). The longevity of such forms suggests that some core food ingredients and their basic preparation may have remained fundamentally unchanged for several centuries, even if the eating habits did change. While poorer nineteenth-century inhabitants, eating a more pulse- and vegetable-based diet, may have used the simple bowls as basic tableware, it is more likely that these practical and versatile forms persisted as food preparation and storage vessels.

\section{Conclusions and future research}

Late nineteenth-century Malta played a strategic role at a time when the British Empire was at its largest and most powerful. In this study I have used traditional archaeological methods to distinguish fabrics and forms, and with the aid of historical accounts situated their production and use within a context of global communication and trade. While many kinds of food were imported from far afield, the majority of everyday foodstuffs were Mediterranean in origin, a pattern that is replicated in the percentages of cooking and food-preparation vessels. Contact between Malta and other parts of the Mediterranean, especially Barbary, Tunis, and the Ionian Islands, ensured traffic of local goods and people. The traditional dependence on Sicily for wheat and other food seems to have been supplemented by others after inclusion within the British Empire, but the connection remained important to Maltese foodways, as seen by the reliance on Sicily for the production of the majority of cooking vessels. Nevertheless, local 
ceramic production provided for most basic needs and continued ${ }_{2}$ despite the in-flow of massproduced British wares. The distinction between the use of Maltese and other Mediterranean ceramic wares for food preparation and storage, and British table wares for eating and drinking suggests a population that was starting to imitate British and north-European dining practices, while the production and preparation of food remained firmly rooted in older traditions. The British Empire was one of commerce and had there been a market for cheap British cooking wares, it would surely have supplied these to the Maltese market. Rather, conscious self-fashioning through the acquisition of both British and Maltese ceramics reflected the changing eating practices and foodways that developed as a result of nineteenthcentury imperialism and a changing Mediterranean.

In a report on the state of Maltese medieval ceramic studies, Molinari and Catajar (1999) lament a situation in which there is insufficient material from secure archaeological contexts from which to put together a museum display. Perhaps the case for later periods is more that the material has not been studied, rather than it has not been found. My current and continuing project has relied on traditional archaeological analysis and would benefit from petrographic, mineralogical, and chemical analyses of fabric samples, as well as food-crust residue analysis to directly link functions with foodways. As part of a larger project recording ceramic and glass assemblages from a range of historic Maltese contexts the future inclusion of such analytical techniques will be invaluable. It is hoped that brief classification and contextualization of nineteenth-century ceramic red wares presented here will act as a starting point and catalyst for future interest and research into the historical archaeology of Malta.

\section{Acknowledgements}

I would like to thank Kenneth Cassar and Godwin Vella (Heritage Malta) for making collections available and providing space in which to record them. Wim De Clercq and Davy 
Herremans provided guidance in the analytical stages of this research and, along with Michael Given, read drafts. Roald Docter kindly provided me with the opportunity to present an earlier version of this paper. Thank you to the many local residents of Birgu who informally discussed their childhood memories of the Inquisitor's Palace and the kenur tal-fuhhar, especially Joseph Cachia. Thank you to Sandro Jung for his support and reading of drafts. Thanks also go to the anonymous peer-reviewers and the editor for their constructive and helpful comments.

\section{References}

Aquilina, J. 2006. Concise Maltese-English English-Maltese Dictionary. Malta: Midsea Books.

Atauz, A.D. 2000. Survey of the Valletta Harbors in Malta 1999. INA Quarterly 27.1: 6-10.

Atauz, A.D. \& McManamon, J. 2001. Underwater Survey of Malta - The Reconnaissance Season of 2000. INA Quarterly 28.2: 22-28.

Badger, G.P.1869. Historical Guide to Malta and Gozo. Malta: P. Calleja.

Barker, G. 1995. A Mediterranean Valley: Landscape Archaeology and Annales History in the Biferno Valley. London: Leicester University Press.

Bintliff, J. 2012. The Complete Archaeology of Greece: from Hunter-Gatherers to the $20^{\text {th }}$ Century A.D. Oxford: Wiley-Blackwell. 
Blagg, T.F.C., Bonanno, A. \& Luttrell, A.T. 1990. Excavations at Hal Milieri, Malta. Malta: University of Malta Press.

Blaquiere, E. 1813. Letters from the Mediterranean, containing a civil and political account of Sicily, Tripoli, Tunis, and Malta. Vol. 1. 2 vols. London: printed for Henry Colburn.

Blouet, B. 1972. The Story of Malta. London: Faber and Faber.

Bonnici, J. \& Cassar, M. 2009. Malta and the British Army Infantry Regiments. Malta: BDL Publishing.

Bruno, B. \& Cutajar, N. 2013. Imported Amphorae as Indicators of Economic Activity in Early Medieval Malta. In: D. Michaelides, P. Pergola \& E. Zanini, eds. The Insular System of the Early Byzantine Mediterranean: Archaeology and history. Oxford: Oxbow, BAR International Series 2523, pp. 15-29.

Buhagiar, C.M. 1998. Museum Notes. Malta Archaeological Review, 3: 41.

Buhagiar, K. 2012. Caves in Context: The Late Medieval Maltese Scenario. In: K.A. Bergsvik \& R. Skeates, eds. Caves in Context: The Cultural Significance of Caves and Rockshelters in Europe. Oxford: Oxbow Books, pp. 153-165.

Buxton, L.H.D. \& Hort, A.V.D. 1921. The Modern Pottery Industry in Malta. MAN, 21: 130 131. 
Cachia, J.M. 2013. pers. comm. Vittoriosa (informal interview 01/11/2013).

Cannon, R. 1847. Historical Record of the Fifty-Third, or The Shropshire Regiment of Foot. London: Parker, Funivali \& Parker.

Carter, T. 1864. Historical Record of the Forty-Fourth, or the East Essex regiment of Foot. London: W.O. Mitchell.

Cassar, C. 1988. Everyday Life in Malta in the Nineteenth and Twentieth Centuries. In: V. Mallia-Milanes ed. The British Colonial Experience 1800-1964. The Impact on Maltese Society. Malta: Mireva Publications.

Coleridge, S.T. 1962. The Notesbooks of Samuel Taylor Coleridge. Vol. 2. 1804-1808. K. Coburn ed. London: Routledge \& Kegen Paul.

Coysh, A.W. \& Henrywood, R.K. 1982. The Dictionary of Blue and White Printed Pottery, 1780-1880. Woodbridge, Suffolk: Antique Collector's Club Ltd.

Digeronimo, I., Grasso, M. \& Pedley, H.M. 1981. Palaeoenvironment and Palaeogeography of Miocene Marls from Southeast Sicily and the Maltese Islands. Palaeogeography, Palaeoclimatology, Palaeoecology 34: 173-189.

Docter, R.F., Vella, N.C., Cutajar, N., Bonanno, A. \& Pace, A. 2012. Rural Malta: First Results of the joint Belgo-Maltese Survey Project. BABESCH, 87: 107-149. 
Devoto, S., Biolchi, S., Bruschi, V.M., Furlani, S., Mantovani, M., Paicentini, D., Pasuti, A. \& Soldati, M. 2012. Geomorphological map of the NW Coast of the Island of Malta (Mediterranean Sea). Journal of Maps 8.1: 33-40.

Egyptian Gazette, 7 December 1882, p. 1.

Fsadni, M. 1999. The Girna: the Maltese Corbelled Stone Hut. Malta: Dominican Publications.

Galizia, A.C. \& Galizia, H.C. 1997. The Food and Cookery of Malta. Totnes, Devon: Prospect Books.

Galt, J. 1812. Voyages and travels in the years 1809, 1810 and 1811, containing statistical, commercial, and miscellaneous observations on Gibraltar, Sardinia, Sicily, Malta, Sergio, and Turkey. London: Printed for T. Cadell and W. Davies.

Gambin, K. 2003. The Inquisitor's Palace, Vittoriosa. Malta: Heritage Books.

Hahs, D.G. 2010. Medieval Malta: Abandoned Villages, Chapels and Farmhouses. MA thesis, Florida State University.Electronic Theses, Treatises and Dissertations. Paper 4334. Accessed 14/02/2014 http://diginole.lib.fsu.edu/etd/4334

Hunt, C. and N.C. Vella. 2008. A view from the countryside: pollen from a field at Mistra Valley, Malta. Malta Archaeological Review [2004/2005] 7: 61-69. 
Lanfranco, G. 1986. The following is a list of the items donated by members of the committee of the Folklore Society to the Director of Museums to be included with the exhibits of the Folklore Museum. L-Imnara, 2.1: 16.

Lang, D. M. 1960. Soils of Malta and Gozo. Colonial Research Studies No. 29. London: HMSO.

Leonard, M.R. 1973. Braziers in the Bodrum Museum. American Journal of Archaeology 77.1: 19-25.

London Gazette, 19 May 1905, p. 3930.

Mallia-Milanes, V. 1993. Introduction to Hospitaller Malta. In: V. Mallia-Mailanes ed. Hospitaller Malta 1530-1798: studies on Early Modern Malta and the Order of St John of Jerusalem. Malta: Mireva Publications, 1-42.

Malta Blue Books (MBB), http://www.nso.gov.mt/site/page.aspx?pageid=392

Martin, R.M. 1837. History of the Possessions of the Honorable East India Company. Vol. 1. London: Whittacker \& Co.

Milanese, M. 2010. Castelsardo: Archeologia di una fortezza dia Doria ogli Spagnoli. Sassari: Carol Delfino editore. 
Milanese, Marco. 2007. Post-Medieval Archaeology in Italy: General Issues and ten years of research (1995-2005). In: S. Gelichi \& M. Librenti, eds. Post-Medieval Archaeology in Italy: A New Agenda. Firenze: Edizioni all'Insegna del Giglio, pp. 41-50.

Molinari, A. \& Cutajar, N. 1999. Of Greeks and Arabs and of Feudal Knights. Malta Archaeological Review, 3: 9-13.

Mommsen, H., Bonanno, A., Chetcuti Bonavita, K., Kakoulli, I., Musumeci, M., Sagona, C., Schwedt, A., Vella, N.C. \& Zacharias, N. 2006. In: Maaggetti, M. \& Messiga, B. eds. Geomaterials in Cultural Heritage.London: Geological Society, Special Publications 257, pp. 81-89.

Muscat, J. 2005. Traditional Boats of Malta. Malta Archaeological Review [2002/2003] 6: 26-40.

Orton, C. \& Hughes, M. 2013. Pottery in Archaeology. Second Edition. Cambridge: Cambridge University Press.

Peacock, D.P.S. 1977. Ceramics in Roman and Medieval Archaeology. In: D.P.S. Peacock, ed. Pottery and Early Commerce: Characterization and Trade in Roman and Later Ceramics. London: Academic Press, pp. 21-33.

Pullicino, J. Cassar. 1947. Folklore Research in Malta. Folklore, 58.3: 328-334. 
Refalo, M. 2010. The Maltese Commercial Class 1870-1914: Business, Families, Networks. Pisa: Plus-Pisa University Press.

Saliba, P.C, Conti, J.M. \& Borg, C. 2002. A Study of Landscape and Irrigation Systems at IsSimblija limits of Dingli, Malta \& Conservation Project. Rome: Consiglio nazionale delle ricerche.

Schmidt, K. \& Bechtold, B. Fabrics of Malta, in FACEM <http://facem.at/img/pdf/2013_12_06_schmidt_bechtold.pdf> [accessed 26 May 2014].

Tallack, W. 1861. Malta, under the Phenicians, Knights, and English. London: A.W. Bennett.

Vella, G. 2013. A New Look at the Old Magna Curia Castellania Building. In: K. Cassar, ed. The Inquisitor's Palace: an architectural gem spanning centuries and styles. Heritage Malta: Malta, pp. 13-21.

Vionis, A.K. 2012. A Crusader, Ottoman and Early Modern Aegean Archaeology: Built Environment and Domestic Material Culture in the Medieval and Post-Medieval Cyclades, Greece (13th-20th centuries AD). Leiden: Archaeological Studies Leiden University 22.

Vroom, J. 2003. After Antiquity. Ceramics and Society in the Aegean from the $7^{\text {th }}$ to the $20^{\text {th }}$ centuries A.C. A Case study from Boetia, Central Greece. Leiden: Archaeological Studies Leiden University 10. 
Vroom, J. 2005. Byzantine to Modern Pottery in the Aegean, 7th to 20th Century: An

Introduction and Field Guide. Utrecht: Parnassus Press.

White, C., Hiranandani, D., Olstad, C.S., Buhargiar, K., Gambin, T. \& Clark, C.M. 2010. The Malta Cistern Mapping Project: Underwater Robot Mapping and Localization within Ancient Tunnel Systems. Journal of Field Robotics 27.4: 399-411.

Wood, J. 1998. Pipes from Malta: a short account of the tobacco pipes found in Dockyard Creek, Birgu. The International Journal of Nautical Archaeology 27.4: 313-330.

Wood, J. 2008. Tobacco pipes from an underwater excavation at the quarantine harbour, Malta. Malta Archaeological Review 7 [2004/2005]: 15-26.

\section{Captions}

\section{Figures}

Figure 1. Map showing location of the Inquisitor's Palace, Malta. Drawn by R. Palmer.

Figure 2. Plan of Inquisitor's Palace, Malta, showing locations of excavations: (1) IPM-GW, (2) IPM-CPMC, (3) IPM-MPY, and (4) IPM-ENE. Drawn by R. Palmer.

Figure 3. Breakdown of ceramics by (a) sherd count, $n=903$, and (b) minimum number of vessel (MNV), $\mathrm{n}=227$.

Figure 4. (a) Base of a spode chinoiserie cup, painted with '53rd Regt' IMP-MPY.1.2/3, (b) Stoneware ginder beer bottle dispaning the name of 'Mortimer \& Co' IPM-ENE.2.34. Photograps: R. Palmer. 
Figure 5. Breakdown of red wares per assemblage by MNV (IPM-CPMC n = 8, IPM-MPY n=22, IPM-GW n=74, IPM-ENE n=45). Photgraphs: R. Palmer.

Figure 6. Sicilian Patti ware: (a) cooking pots, (b) flat-based pans, and (c) bowls. Drawn by R. Palmer.

Figure 7. Sicilian Patti ware: tigan (a) IPM-GW1.4, (b) IPM-GW.1.9 interior, (c) IPMGW.1.9 exterior exhibiting sooting; a Type 1 cooking pot (d) IPM-CPMC.1.49/50.

Photgraphs: R. Palmer.

Figure 8. Imported red wares: (a) and (b) dishes, (c) and (d) storage vessels, (e) a globular pot, and (f) a jug. Drawn by R. Palmer.

Figure 9. Imported jug. IPM-ENE.3.165. Photograph: R. Palmer.

Figure 10. Sketch by Pietro Paolo Caruana illustrating water carrying vessels (no 15, 1831. National Museum of Fine Arts, Malta). Reproudced with the kind permission of Heritage Malta.

Figure 11. Detail of a selection of local fabrics. Photographs. R. Palmer.

Figure 12. Local red wares: (a) type 1 bowls, (b) type 2 bowls or żingliet, (c) water-carrying jars, (d) type 1 storage jars, and (e) type 2 storage jars. Drawn by R. Palmer.

Figure 13. Local red ware kenur tal-fuhhar. Drawn by R. Palmer.

Figure 14. Kenur tal-fulhhar (a) showing handle and white-slip painted decoration IPMGW5.25; (b) exterior showing handle and (c) interior with ring-shelf of IPM-GW.8.94. Photgraphs: R. Palmer.

Figure 15. A Maltese limestone kenur on display at the Inquisitor's Palace Museum, undated. Photo: R. Palmer.

Figure 16. The cooking range at the Inquisitor's Palace Museum. Photo: R. Palmer. 


\section{Tables}

Table 1. Breakdown of ceramics from the Inquisitor's Palace site.

Table 2. Breakdown of red wares by form.

Table 3. Breakdown of red wares by assemblage.

Table 4. Comparison of Buxton \& Hort's (1921) nomenclature with local forms.

\footnotetext{
${ }^{1}$ Defined here as the study of archaeological study of the post- A.D. 1500 world.

${ }^{2}$ All grid references taken from Google Earth.

${ }^{3}$ The assemblage has not been studied and published so it is impossible to be certain.

${ }^{4}$ Imports of coal and charcoal are no longer recorded in the Malta Blue Books in the mid-late 1800 s.

${ }^{5}$ Plan held at the Inquisitors Palace Museum, no archival reference. The plan refers to Officers' quarters and Royal Engineers' stores, indicating a nineteenth-century date commensurate with the buildings use as an officers' mess.
} 